\title{
PERAN GURU IPS SEBAGAI PENDIDIK DAN PENGAJAR DALAM MENINGKATKAN SIKAP SOSIAL DAN TANGGUNG JAWAB SOSIAL SISWA SMP
}

\author{
Edy Surahman, Mukminan \\ SMPN 1 Pangkajene Sidrap, Universitas Negeri Yogyakarta \\ surahman_edy@yahoo.co.id \& mukminan@yahoo.co.id
}

\begin{abstract}
Abstrak
Penelitian ini bertujuan untuk: (1) mengetahui peran guru IPS sebagai pendidik dan pengajar di SMP Negeri 1 Pangkajene Sidrap; (2) mengetahui sikap sosial siswa SMP Negeri 1 Pangkajene Sidrap; (3) mengetahui tanggung jawab sosial siswa SMP Negeri 1 Pangkajene Sidrap; (4) mengetahui pengaruh peran guru IPS sebagai pendidik dan pengajar dalam meningkatkan sikap sosial siswa SMP Negeri 1 Pangkajene Sidrap; dan (5) mengetahui pengaruh peran guru IPS sebagai pendidik dan pengajar dalam meningkatkan tanggung jawab sosial siswa SMP Negeri 1 Pangkajene Sidrap. Analisis data penelitian ini menggunakan analisis regresi linear sederhana. Hasil penelitian menunjukkan: (1) sumbangan peran guru IPS sebagai pendidik dan pengajar sebesar 62,7\%; (2) sumbangan sikap sosial siswa SMP Negeri 1 Pangkajene Sidrap sebesar 67,1\%; (3) sumbangan tanggung jawab sosial siswa SMP Negeri 1 Pangkajene Sidrap sebesar 62,7\%; (4) peran guru IPS sebagai pendidik dan pengajar terbukti berpengaruh positif dalam meningkatkan sikap sosial siswa; (5) peran guru IPS sebagai pendidik dan pengajar juga terbukti berpengaruh positif dalam meningkatkan tanggung jawab sosial siswa. Jadi dapat disimpulkan bahwa guru mata pelajaran IPS sebagai pendidik dan pengajar dapat mempengaruhi sikap sosial dan tanggung jawab sosial siswa dengan cara guru memberikan contoh langsung dan spontan pada siswa.
\end{abstract}

Kata Kunci: peran guru, sikap sosial, tanggung jawab sosial, guru IPS

\section{THE ROLE OF SOCIAL STUDIES TEACHER AS AN EDUCATOR AND TEACHERS ON INCRASE THE SOCIAL ATTITUDE AND SOCIAL RESPONSIBILITY STUDENTS OF SMP}

Edy Surahman, Mukminan

SMPN 1 Pangkajene Sidrap, Universitas Negeri Yogyakarta surahman_edy@yahoo.co.id \& mukminan@yahoo.co.id

\begin{abstract}
This study aims to: (1) determine the role of Social Studies teachers as educators and teachers in SMP Negeri 1 Pangkajene Sidrap; (2) determine social attitudes of students of SMP Negeri 1 Pangkajene Sidrap; (3) determine the social responsibility of students of SMP Negeri 1 Pangkajene Sidrap; (4) the effect of the role of Social Studies teachers as educators and teachers on the social attitudes of students SMP Negeri 1 Pangkajene Sidrap; and (5) the effect of the role of Social Studies teachers as educators and teachers to social responsibility of students SMP Negeri 1 Pangkajene Sidrap. The data analysis used simple regression analysis. Finding of this research shown (1) contribution the role of Social Studies teachers as educators and teachers is 62.7\%; (2) contribution social attitudes of students SMP Negeri 1 Pangkajene Sidrap is 67.1\%; (3) contribution social responsibility of students SMP Negeri 1 Pangkajene Sidrap is 62.7\%; (4) the role of Social Studies teachers as educators and teachers proved to be a positive influence on increase students' social attitude; (5) the role of Social Studies teachers as educators and teachers also proved a positive influence on increase the students' social responsibility. So it can be concluded that the Social Studies teachers as educators and teachers can influence social attitudes and social responsibility of students with the teacher gives examples for students directly and spontaneously.
\end{abstract}

Keywords: role of teachers, social attitude, and social responsibility, social studies teachers 


\section{Pendahuluan}

Pendidikan adalah usaha sadar untuk menumbuh kembangkan potensi sumber daya manusia melalui kegiatan pengajaran. Dalam Pasal 1 Undang-undang Republik Indonesia Nomor 20 Tahun 2003 tentang Sistem Pendidikan Nasional menyebutkan bahwa: Pendidikan adalah usaha secara sadar dan terencana untuk mewujudkan suasana belajar dan proses pembelajaran agar peserta didik secara aktif mengembangkan potensi dirinya untuk memiliki kekuatan spiritual keagamaan, pengendalian diri, kepribadian, kecerdasan, akhlak mulia, serta ketrampilan yang diperlukan dirinya, masyarakat, bangsa, dan negara. Pelaksanaan pendidikan harus sesuai dengan tujuan yang diharapkan pada pasal selanjutnya, pasal 3; Pendidikan nasional berfungsi mengembangkan kemampuan dan membentuk watak serta peradaban bangsa yang bermartabat dalam mencerdaskan kehidupan bangsa. Berarti pelaksanaan proses pendidikan diharapkan dapat membentuk manusia yang beriman dan bertakwa kepada Tuhan Yang Maha Esa. Pendidikan tidak hanya melahirkan seseorang yang ahli dalam bidang tertentu, namun termasuk juga bagaimana seseorang mampu membawa diri dalam lingkungan bermasyarakat, berbangsa dan bernegara sesuai dengan norma dan aturan yang berlaku.

Paradok dengan maksud dan fungsi pendidikan di atas, beberapa fenomena sosial yang kurang relevan dilakukan oleh siswa akhir-akhir ini, seperti: tindak kriminal, kekerasan, pelecehan seksual, tawuran antar pelajar, destruksi tanggung jawab sosial, dan sebagainya. Meskipun tidak mencerminkan siswa pada umumnya, namun terjadi berulang kali sampai sekarang, sehingga patut menjadi perhatian bebagai pihak; pemerintah, kalangan pendidikan, keluarga, dan masyarakat.

Pendidikan di sekolah mendapat kritik terkait kurangnya pembangunan aspek afektif di banding kognitif. Ketidak seimbangan ini ditengarai sebagai salah satu simpul fenomena 'kekerasan' di atas. Munculnya pernyataan diberbagai diskusi; tercetak generasi yang pintar, tetapi tidak memiliki karakter yang dibutuhkan bangsa. Merupakan akumulasi dari kritik pembangunan aspek afektif yang tertinggal dibanding kognitif. Pernyataan ini seolah mendapat pembenaran oleh kasus-kasus kekerasan yang dilakukan guru terhadap siswa (UNICEF, 2014).

Disisi lain pada saat yang sama masyarakat mempertontonkan benturan-benturan asosial, seperti: konflik, kekerasan, kenakalan remaja, pelecehan seksual, terorisme dan lain sebagainya. Modal sosial bangsa Indonesia yang penuh dengan nilai-nilai kearifan seolah tidak mendapat tempat, sampai melahirkan keprihatinan, solidaritas, keadilan, persatuan, dan nilai-nilai lainnya yang bersumber dari sosio budaya bangsa (nilai-nilai luhur).

Berbagai perilaku sosial di sekolah dan masyarakat tersebut masih terjadi secara sporadis dan diperlihatkan oleh berbagai media, keadaan ini tentu beresonansi dengan berbagai pihak termasuk siswa lain yang sedang dalam masa pembangungan karakter. Akibatnya secara perlahan siswa mengalami pergeseran tata krama kehidupan sosial dan etika moral dalam praktik kehidupan sekolah. Pergeseran ini nampak terjadi di berbagai sekolah di Indonesia (UNICEF, 2014).

Pendidikan merupakan salah satu yang bertanggung jawab besar dalam melahirkan warga negara Indonesia yang memiliki karakter kuat sebagai modal dalam membangun peradaban tinggi dan unggul. Karakter bangsa yang kuat merupakan produk dari pendidikan. Ketika mayoritas karakter masyarakat kuat, positif, tangguh peradaban yang tinggi dapat dibangun dengan baik dan sukses. Sebaliknya, jika mayoritas karakter masyarakat negatif, karakter negatif dan lemah mengakibatkan peradaban yang di bangun menjadi lemah.

Terkait dengan tanggung jawab pendidikan tersebut, Ilmu Pengetahuan Sosial adalah mata pelajaran di sekolah yang di desain atas dasar fenomena, masalah dan realitas sosial dengan pendekatan interdisipliner yang melibatkan berbagai cabang ilmu-ilmu sosial dan humaniora seperti kewarganegaraan, sejarah, geografi, ekonomi, sosiologi, antropologi, pendidikan. Karena itu, IPS dapat dikatakan sebagai studi mengenai perpaduan antara ilmu-ilmu dalam rumpun ilmu-ilmu sosial dan juga humaniora untuk melahirkan pelakupelaku sosial yang dapat berpartisipasi dalam memecahkan masalah-masalah sosio kebangsaan. Bahan kajiannya menyangkut peristiwa, seperangkat fakta, konsep dan generalisasi yang berkait dengan isu-isu aktual, gejala dan 
masalah-masalah atau realitas sosial serta potensi daerah.

Sebutan IPS di Indonesia adalah sebuah kesepakatan untuk menunjuk istilah lain dari social studies. Menunjuk sifat keterpaduan dari ilmu-ilmu sosial atau integrated social sciences. Jadi sifat keterpaduan itu mestinya menjadi ciri pokok mata kajian yang disebut IPS. IPS adalah studi integratif tentang kehidupan manusia dalam berbagai dimensi ruang dan waktu dengan segala aktivitasnya. Dalam rumusan yang lain, IPS merupakan kajian yang terkait dengan kehidupan sosial kemasyarakatan berserta lingkungannya untuk kepentingan pendidikan dan pembentukan para pelaku sosial.

Nursid (2008, pp. 1-3) mengemukakan bahwa IPS masih bersifat elementer bersifat dasar dan fundamental belaka. Pada tingkat yang lebih tinggi ilmu ini sudah berkembang sedemikian rupa, karena itu IPS yang dipelajari pada perguruan tinggi disebut dengan istilah lain yaitu social science. Masih menurut Nursid (2008, p.1, p.17), pendidikan IPS adalah suatu penyederhanaan disiplin ilmu-ilmu sosial, ideologi negara dan disiplin ilmu lainnya serta masalah-masalah sosial terkait yang diorganisasikan dan disajikan secara ilmiah dan psikologis untuk tujuan pendidikan pada tingkat pendidikan dasar dan menengah.

IPS dalam pendidikan merupakan suatu konsep yang mengembangkan pengetahuan, sikap, dan keterampilan sosial dalam rangka membentuk dan mengembangkan pribadi warga negara yang baik, juga telah menjadi bagian dari wacana kurikulum dan sistem pendidikan di Indonesia, dan merupakan program pendidikan sosial pada jalur pendidikan sekolah. Sebagaimana diungkapkan oleh Nursid (2008, p. 20) bahwa Mata pelajaran IPS bertujuan mengembangkan potensi peserta didik agar peka terhadap masalah sosial yang terjadi dimasyarakat, memiliki sikap mental positif terhadap perbaikan segala ketimpangan yang terjadi, dan terampil mengatasi setiap masalah yang terjadi sehari-hari baik yang menimpa dirinya sendiri maupun yang menimpa kehidupan masyarakat.

Mencermati uraian tentang pengertian dan tujuan IPS, maka pendidikan IPS sangat erat kaitannya dengan berbagai fenomena asosial yang dilakukan siswa akhir-akhir ini. Pendidikan karakter dapat dimaknai sebagai pendidikan nilai, pendidikan moral atau pen- didikan budi pekerti. makna ini memiliki arah dan tujuan yang sama dengan tujuan pembelajaran IPS, yakni sama-sama bertujuan agar peserta didik dapat menjadi warga negara yang baik. Secara konseptual, istilah pendidikan nilai ini sering disamakan dengan pendidikan religius, pendidikan budi pekerti, pendidikan akhlak mulia, pendidikan moral atau pendidikan karakter itu sendiri. Pendidikan karakter, pendidikan moral, atau pendidikan budi pekerti itu dapat dikatakan sebagai upaya untuk mempromosikan dan menginternalisasikan nilai-nilai utama, atau nilai-nilai positif kepada warga masyarakat agar menjadi warga bangsa yang percaya diri, tahan uji dan bermoral tinggi, demokratis dan bertanggung jawab serta survive dalam kehidupan bermasyarakat. Dengan demikian, pendidikan karakter merupakan proses pembudayaan dan pemanusiaan.

Sekolah harus menjadi sebuah komunitas dan wahana persaudaraan tempat berkembangnya nilai-nilai kebaikan atau nilainilai utama. Pendidikan karakter akan senantiasa mengembangkan akhlak mulia dan kebiasaan yang baik bagi para peserta didik. Dalam pengembangan pendidikan karakter, guru harus juga bekerja sama dengan keluarga atau orang tua/wali peserta didik. Nilai kebaikan yang perlu dihayati dan dibiasakan dalam kehidupan peserta didik agar tercipta kehidupan yang harmonis di dalam keluarga dan masyarakat. Beberapa nilai itu antara lain kasih sayang, pengendalian diri, saling menghargai atau menghormati, kerja sama, tanggung jawab, dan ketekunan.

Pembiasaan penerapan norma-norma sosial harus dimulai bersama oleh semua elemen yang ada di sekolah, tidak dapat disanggah terutama peran guru. Bertolak dari uraian mata pelajaran IPS di atas, maka peran guru IPS sangat diharapkan dalam upaya membangun perilaku siswa. Guru mata pelajaran IPS harus mampu mengimplementasikan perannya sebagaimana maksud mata pelajaran IPS. Sehingga mata pelajaran IPS selain memiliki dimensi integratif, dalam arti mengukuhkan moral intelektual peserta didik atas dasar nilai-nilai kebaikan, sehingga menjadi pribadi yang mantap dan tahan uji, pribadi-pribadi yang cendekia, mandiri dan bernurani, tetapi juga bersifat kuratif secara personal maupun sosial. Hal ini bukan berarti mengecilkan peran dari guru mata pelajaran lain. 
Guru dalam keadaan seperti ini dihadapkan pada tuntutan yang semakin berat, terutama untuk mempersiapkan siswa agar mampu menghadapi berbagai dinamika perubahan yang berkembang pesat. Perubahan bukan saja berkaitan dengan perkembangan ilmu pengetahuan dan teknologi, tetapi juga menyentuh perubahan dan pergeseran aspek nilai moral yang terjadi dalam kehidupan bermasyarakat. Peran guru sangat diperlukan dalam upaya memperbaiki perilaku siswa, terutama membantu menumbuhkan rasa tanggung jawab sosial. Guru dapat memberi dorongan, tugas pengawasan dan pembinaan serta tugas yang berkaitan dengan mendisiplinkan peserta didik agar peserta didik menjadi patuh terhadap aturan sekolah dan norma hidup dalam keluarga dan masyarakat berdasarkan kesadaran.

Fakta di lapangan menunjukkan bahwa masih banyak guru yang lebih berorientasi pada penguasaan dan pemahaman anak terhadap materi pelajaran tanpa mempertimbangkan pembentukan karakter anak sebagai efek hasil belajar, sehingga materi pelajaran kurang bahkan tidak mewarnai sama sekali terhadap sikap dan kepribadian anak. Banyak guru yang menjadikan evaluasi sebagai tujuan, tidak menjadikan evaluasi sebagai alat untuk mencapai tujuan. Hasil observasi penulis pada hari Senin tanggal 6 Juli sampai hari Kamis tanggal 23 juli 2015 di SMP Negeri 1 Pangkajene Sidrap, mendapatkan tanda-tanda penurunan tanggung jawab sosial siswa. Misalnya siswa: menyontek pada saat ujian sekolah, kurang mampu mengembangkan potensi yang dimiliki melalui karya, kurang tumbuh sikap saling membantu dan tenggang rasa antar siswa maupun terhadap guru, penurunan empati; kurang peka terhadap siswa lainnya, lebih mementingkan dirinya dan kelompoknya; kecurangan dan ketidak terbukaan dalam pelaksanaan pembelajaran.

Tanda penurunan tanggung jawab sosial pada siswa SMP Negeri 1 Pangkajene Sidrap tersebut perlu mendapat perhatian berbagai pihak yang terkait agar dapat dicegah. Dalam rangka pencegahan ini guru memiliki peran cukup besar. Terlebih guru mata pelajaran IPS yang materi pelajarannya berkaitan langsung dengan sikap sosial dan tanggung jawab sosial siswa. Dalam upaya membantu usaha guru khususnya guru mata pelajaran IPS memperbaiki sikap dan tanggung jawab tersebut penelitian ini dilakukan.

\section{Peran Guru}

Menurut Wrightman Usman (2006, p. 4) "peran guru adalah terciptanya serangkaian tingkah yang saling berkaitan yang dilakukan dalam situasi tertentu serta berhubungan dengan kemajuan perubahan tingkah laku dan perkembangan peserta didik yang menjadi tujuannya". Darmadi (2010, p. 53) mengemukakan fungsi dan peran guru sebagai pendidik dan pengajar sebagai berikut:

Bahwa setiap guru harus memiliki kestabilan emosi, ingin memajukan peserta didik, bersikap realitas, dan terbuka, serta peka terhadap pengembangan, terutama inovasi pendidikan. Untuk mencapai semua itu, guru harus memiliki pengetahuan yang luas, menguasai berbagai jenis bahan pembelajaran, menguasai teori dan praktik pendidikan, serta menguasai kurikulum dan metodologi pembelajaran.

Sejalan dengan pendapat tersebut Rusyan (1990, p.14) mengemukakan bahwa fungsi dan peran guru adalah sebagai berikut, fungsi guru: (1) pendidik dan pengajar, (2) pelaksana administrasi akan dihadapkan kepada administrasi-administrasi yang harus dikerjakan di sekolah, (3) pengelola PBM, harus menguasai situasi belajar mengajar baik di dalam kelas maupun di luar kelas.

Guru sebagai pendidik yaitu dimana guru menjadi tokoh panutan dan identifikasi bagi peserta didik dan lingkungannya (Mulyasa, 2011, p.37). Peran guru sebagai pendidik mengharuskan seorang guru untuk menjaga kewibawaannya, dengan bertanggung jawab, disiplin, mandiri, dan berkepribadian baik agar bisa menjadi contoh bagi siswanya.

Guru sebagai pengajar yaitu guru menjalankan tugasnya dalam merencanakan dan melaksanakan pembelajaran di sekolah. Selain mengajar, guru juga harus berusaha agar terjadi perubahan sikap, keterampilan, kebiasaan, hubungan sosial, apresiasi, dan sebagainya melalui pemebelajaran yang disampaikan (Hamalik, 2009, p. 124).

Dalam membantu siswa untuk belajar dengan baik, guru dapat melakukan beberapa cara, seperti penjelasan dari Hamond (2006, p. 269) bahwa:

"this includes helping students develop some of their own strategies for organizing and retaining information (task 
analysis, webbing, outlining), tackling texts, writing, and approaching various tasks and problems".

Maksudnya yaitu guru membantu siswa untuk mengembangkan beberapa strategi untuk bisa mengatur dan mempertahankan informasi tentang analisis tugas dan memecahkan masalah.

Somantri dalam Sapriya (2009, p. 11) bahwa: "Pendidikan IPS adalah seleksi dari disiplin ilmu-ilmu sosial dan humaniora, serta kegiatan dasar manusia yang diorganisasikan dan disajikan secara ilmiah dan psikologis untuk tujuan pendidikan". Ciri khas IPS sebagai mata pelajaran pada jenjang pendidikan dasar dan menengah adalah sifat terpadu (integrated) dari sejumlah mata pelajaran dengan tujuan agar mata pelajaran ini lebih bermakna bagi peserta didik sehingga pengorganisasian materi atau bahan pelajaran disesuaikan dengan lingkungan, karakteristik dan kebutuhan peserta didik.

Pada dasarnya tujuan dari pendidikan IPS secara umum adalah untuk mendidik dan memberi bekal kemampuan dasar kepada siswa untuk mengembangkan diri sesuai dengan bakat, minat, kemampuan dan lingkungannya, serta berbagai bekal bagi siswa untuk melanjutkan pendidikan ke jenjang lebih tinggi. Nursid dalam Gunawan (2011, p.94) menyatakan bahwa "Tujuan Pendidikan IPS adalah membinaanak didik menjadi warga negara yang baik, yang memiliki pengetahuan, dan kepedulian sosial". Secara rinci Hamalik Gunawan (2011, p. 94) merumuskan "tujuan Pendidikan IPS adalah berorientasi pada tingkah laku para siswa, yaitu (1) pengetahuan dan pemahaman (2) sikap hidup belajar, (3) nilainilai sosial dan sikap (4) keterampilan".

Bila ditinjau dari ruang lingkup, objek dan tujuannya maka dapat dikatakan bahwa Ilmu Pengetahuan Sosial (IPS) adalah suatu mata pelajaran yang mempelajari, menelaah dan menganalisis gejala dan masalah sosial dalam masyarakat ditinjau dari berbagai aspek kehidupan secara terpadu. Sebagaimana penjelasan dari Massialas \& Allen (1996, p. 3), “... social studies in this guide is defined as an area within the school curriculum that draws ideas from a variety of areas, including history, the social sciences, and the humanities, for purposes of citizenship education". Mereka menjelaskan bahwa IPS mencakup ide-ide tentang berbagai daerah, yang meliputi sejarah, ilmu-ilmu sosial, dan humaniora untuk tujuan pendidikan kewarganegaraan.

Fraenkel (Sardjiyo 2007, p. 25) membagi tujuan IPS dalam empat kategori yaitu: 1) Pengetahuan 2) Keterampilan 3) Sikap 4) Nilai. Pengetahuan adalah kemahiran dan pemahaman terhadap sejumlah informasi dan ide-ide. Tujuan pengetahuan ini membantu siswa untuk belajar lebih banyak tentang dirinya, fisiknya dan dunia sosial. Keterampilan adalah pengembangan kemampuan-kemampuan tertentu yang dimiliki oleh siswa. Sikap adalah kemahiran mengembangkan dan menerima keyakinan-keyakinan, interes, pandangan-pandangan, dan kecenderungan tertentu. Sedangkan nilai adalah kemahiran memegang sejumlah komitmen yang mendalam, mendukung ketika sesuatu dianggap penting dengan tindakan yang tepat.

Sikap sosial menurut Ahmadi (2009, p.149) adalah kesadaran individu yang menentukan perbuatan yang nyata, yang berulang-ulang terhadap objek sosial. Sudarsono (1997, p.216) mendefinisikan social attitudes (sikap sosial) sebagai perbuatan-perbuatan atau sikap yang tegas dari seseorang atau kelompok di dalam keluarga atau masyarakat. Sikap sosial dapat besifat positif maupun negatif, tergantung pengaruh yang diberikan oleh lingkungan dan penerimaan seseorang.

Penilaian sikap sosial siswa dapat menggunakan acuan penilaian kompetensi peserta didik Sekolah Menengah Pertama (SMP) dari Kemdikbud (2014, p.7) sebagai berikut:

Pada jenjang SMP/MTs, kompetensi sikap spiritual mengacu pada KI-1: Menghayati dan menghargai ajaran agama yang dianutnya, sedangkan kompetensi sikap sosial mengacu pada KI-2: Menghargai dan menghayati perilaku jujur, disiplin, peduli (toleransi, gotong royong), santun, percaya diri dalam berinteraksi secara efektif dengan lingkungan sosial dan alam dalam jangkauan pergaulan dan keberadabannya.

Kompetensi sikap sosial mengacu pada KI-2: menghargai dan menghayati perilaku jujur, disiplin, peduli (toleransi, gotong royong), santun, percaya diri dalam berinteraksi secara efektif dengan lingkungan sosial dan alam dalam jangkauan pergaulan dan keberadabannya. 
Dalam penilaian sikap sosial siswa, jujur, disiplin, peduli (toleransi, gotong royong), santun dan percaya diri merupakan indikator dalam mengamati tinjauan variabel sikap sosial siswa, aspek sikap sosial untuk mata pelajaran tertentu bersifat relatif generik, namun beberapa materi pokok tertentu ada yang berbeda. Guru dapat menambahkan sikap-sikap tersebut menjadi perluasan cakupan penilaian sikap. Perluasan cakupan penilaian sikap didasarkan pada karakterisitik setiap mata pelajaran. Melalui mata pelajaran IPS, guru dapat melihat sikap sosial siswa dari rasa ingin tahu siswa, keterbukaan siswa, sikap kritis siswa, sikap siswa yang menghargai pendapat orang lain, serta sikap siswa dalam mencintai tanah airnya.

Penelitian Risthantri (2015) mengemukakan ada hubungan antara pola asuh orang tua dan ketaatan beribadah dengan perilaku sopan santun peserta didik. Perlunya sikap baik dalam berbahasa maupun bertingkah laku.

Tabel 1. Indikator Sikap Sosial

\begin{tabular}{|c|c|c|}
\hline No & Sikap Sosial & Pengertian \\
\hline 1 & Jujur & $\begin{array}{l}\text { Adalah perilaku dapat } \\
\text { dipercaya dalam perkataan, } \\
\text { tindakan, dan pekerjaan. }\end{array}$ \\
\hline 2 & Disiplin & $\begin{array}{l}\text { Adalah tindakan yang } \\
\text { menunjukkan perilaku tertib } \\
\text { dan patuh pada berbagai } \\
\text { ketentuan dan peraturan. }\end{array}$ \\
\hline 3 & Toleransi & $\begin{array}{l}\text { Adalah sikap dan tindakan } \\
\text { yang menghargai } \\
\text { keberagaman latar belakang, } \\
\text { pandangan, dan keyakinan. }\end{array}$ \\
\hline 4 & $\begin{array}{l}\text { Gotong } \\
\text { royong }\end{array}$ & $\begin{array}{l}\text { Adalah bekerja bersama sama } \\
\text { dengan orang lain untuk } \\
\text { mencapai tujuan bersama } \\
\text { dengan saling berbagi tugas } \\
\text { dan tolong menolong secara } \\
\text { ikhlas. }\end{array}$ \\
\hline 5 & $\begin{array}{l}\text { Sopan atau } \\
\text { santun }\end{array}$ & $\begin{array}{l}\text { Adalah sikap baik dalam } \\
\text { pergaulan baik dalam } \\
\text { berbahasa maupun bertingkah } \\
\text { laku. Norma kesantunan } \\
\text { bersifat relatif, artinya yang } \\
\text { dianggap baik/santun pada } \\
\text { tempat dan waktu tertentu bias } \\
\text { berbeda pada tempat dan } \\
\text { waktu yang lain. }\end{array}$ \\
\hline 6 & Percaya diri & $\begin{array}{l}\text { adalah kondisi mental atau } \\
\text { psikologis seseorang yang } \\
\text { memberi keyakinan kuat untuk } \\
\text { berbuat atau bertindak }\end{array}$ \\
\hline
\end{tabular}

Penilaian sikap sosial dilakukan untuk mengetahui perkembangan sikap sosial siswa dalam menghargai, menghayati, dan berperilaku jujur, disiplin, peduli (toleransi, gotong royong), santun, percaya diri, dalam berinteraksi secara efektif dengan lingkungan sosial dan alam dalam jangkauan pergaulan dan keberadaannya (Kementerian Pendidikan dan kebudayaan, 2015, p. 32). Permendikbud Nomor 53 tahun 2015 menjelaskan bahwa:

Penilaian hasil belajar oleh pendidik adalah proses pengumpulan informasi/ data tentang capaian pembelajaran peserta didik dalam aspek sikap, aspek pengetahuan, dan aspek keterampilan yang dilakukan untuk memantau proses, kemajuan belajar, dan perbaikan hasil belajar melalui penugasan dan evaluasi hasil belajar.

Jadi penilaian sikap menjadi salah satu komponen penting yang harus dicapai oleh siswa dalam proses pembelajaran di sekolah. Untuk itu peran guru sangat diperlukan dalam pembentukan sikap sosial siswa selama di sekolah. Karena tanpa ada guru yang mendidik dan mengajar siswa di sekolah, sikap sosial siswa akan sulit untuk dibentuk dan dikembangkan.

Inglis \& Aers (2008, p. 162) menyebutkan "responsibility is a concept and a value with multiple but intuitively well-understood meaning". Maksudnya yaitu tanggung jawab merupakan sebuah konsep dan beberapa nilai akan tetapi maknanya sulit dipahami.

Simorangkir (1987, p. 155) memberikan pengertian tanggung jawab sosial sebagai kemampuan manusia dalam kehidupan bermasyarakat dalam menjaga keseimbangan antara perilaku yang ditampilkan dengan harapan sesuai dengan status sosialnya (expectation).

Guru yang membantu siswa untuk mengemban tanggung jawab sosial berarti guru telah memberikan kekuasaan terhadap siswa dalam pengambilan keputusan. Seperti yang dijelaskan oleh Hellison (2003, p. 13), "and helping students take personal and social responsibility means sharing power with students and gradually shifting decision making to them. TPSR does not mean getting inside kids' heads but getting them inside their own heads".

Indikator dalam penilaian tanggung jawab sosial yaitu: menerima konsekuensi da- 
ri setiap tindakan dan keputusan yang dilakukan, melaksanakan tugas individu dengan baik, tidak menyalahkan orang lain, mengembalikan barang yang dipinjam, tepat janji, dan konsekuen dengan perkataan.

Tabel 2. Indikator Tanggung Jawab Sosial

\begin{tabular}{cl}
\hline No & Tanggung Jawab Sosial \\
\hline 1 & Menerima konsekuensi dari tindakan dan \\
& keputusan yang dilakukan. \\
2 & Melaksanakan tugas individu dengan baik \\
3 & Tidak menyalahkan orang lain \\
4 & Mengembalikan barang yang dipinjam \\
5 & Tepat janji \\
6 & Konsekuen dengan perkataan \\
\hline
\end{tabular}

Sikap sosial siswa merupakan salah satu bentuk dari karakter siswa. Menurut Mulyasa (2011, p.63) guru berperan penting dalam keberhasilan pendidikan karakter di sekolah. Dalam pendidikan karakter guru harus memulai dari dirinya sendiri agar apaapa yang dilakukannya dengan baik bisa menjadi baik pula pengaruhnya terhadap siswa. Karena pendidikan menjadi sulit untuk menghasilkan sesuatu yang baik tanpa dimulai oleh guru-gurunya yang baik. Karakter siswa dapat berkembang atas campur tangan guru, sebagaimana yang diungkapkan.

Zuriah (2007, p.39) bahwa keselarasan antara kata-kata dan tindakan dari guru akan sangat berarti dalam pembentukan karakter siswa. Jika guru mengajarkan pada siswanya untuk disiplin di kelas, akan tetapi guru tersebut sering terlambat masuk kelas, tentunya akan memberikan efek yang kurang baik terhadap penanaman sikap sosial pada diri siswa. Oleh karena itu, guru yang ingin mengajarkan kedisiplinan pada siswa juga harus bersikap disiplin terlebih dahulu. Selain itu, sikap sosial siswa dapat terbentuk apabila guru sebagai pendidik memberikan contoh tindakan sikap sosial, tidak hanya memberikan teori saja.

Seperti yang dijelaskan oleh Lickona (2013, p. 118) bahwa dalam mengajarkan pendidikan kakarter guru sebagai pendidik harus menggabungkan antara contoh yang baik dengan pengajaran langsung. Sehingga siswa mampu memahami dan meniru sikap sosial untuk diterapkan dalam dirinya.

Pengembangan tanggung jawab sosial siswa bisa melalui kompetensi dan kepiawai- an guru dalam mengelola kelas, membangun tim belajar dalam kelas dan menciptakan suasana pembelajaran bersama yang saling mendukung proses belajar (Koesoema, 2009, p. 159). Guru dapat memberikan kepercayaan kepada siswa yang memiliki kemampuan lebih untuk menjadi tutor bagi rekan sekelompoknya dalam mendiskusikan materi pelajaran. Melalui cara tersebut guru telah mengembangkan tanggung jawab sosial dalam diri siswa di lingkungan sekolah.

Penelitian Wijaya (2015) membuktikan bahwa terdapat pengaruh yang signifikan antara peranan guru dalam pembentukan perilaku bertanggung jawab peserta didik di SMA N 15 Bandar Lampung. Perilaku tanggung jawab siswa dapat dilihat pada tiga indikator yaitu mengerjakan tugas yang diberikan di sekolah, melaksanakan tata tertib sekolah dan menjaga fasilitas sekolah. Di SMA N 15 Bandar Lampung guru telah memperbaiki sikap dan tindakannya dalam hal tanggung jawab sehingga dapat dicontoh oleh siswa.

Dari hasil penelitian Juniar (2010), ditemukan bahwa upaya-upaya yang dilakukan guru dalam membina tanggung jawab sosial siswa, yaitu dengan mendorong siswa untuk aktif dalam kegiatan ekstrakurikuler, penyusunan dan pemberlakuan tata tertib sekolah dengan tegas, serta pemberian sanksi secara tegas terhadap pelanggaran-pelanggaran yang dilakukan siswa. Pembinaan yang dilakukan oleh para guru telah mencapai hasil yang cukup memuaskan karena adanya kerja sama yang terjalin baik antara guru dan siswa.

Berdasarkan uraian tersebut, penelitian ini bertujuan untuk: : (1) mengetahui peran guru IPS sebagai pendidik dan pengajar di SMP Negeri 1 Pangkajene Sidrap; (2) mengetahui sikap sosial siswa SMP Negeri 1 Pangkajene Sidrap; (3) mengetahui tanggung jawab sosial siswa SMP Negeri 1 Pangkajene Sidrap; (4) mengetahui pengaruh peran guru IPS sebagai pendidik dan pengajar dalam meningkatkan sikap sosial siswa SMP Negeri 1 Pangkajene Sidrap; dan (5) mengetahui pengaruh peran guru IPS sebagai pendidik dan pengajar dalam meningkatkan tanggung jawab sosial siswa SMP Negeri 1 Pangkajene Sidrap.

\section{Metode Penelitian}

Pendekatan penelitian yang digunakan yaitu penelitian deskriptif kuantitatif. 
Pendekatan ini dipilih karena penelitian ini bertujuan untuk menguji hipotesis dan mendiskripsikan seberapa besar peran, sikap sosial siswa dan tanggung jawab sosial siswa SMP Negeri 1 Pangkajene Sidrap.

Penelitian ini dilaksanakan di SMP Negeri 1 Pangkajene Sidrap, yang dilaksanakan pada bulan Januari tahun 2016 sampai dengan Maret tahun 2016. Populasi dalam penelitian ini yaitu siswa SMP Negeri 1 Pangkajene Sidrap yang berjumlah 274 siswa. Teknik pengambilan sampel menggunakan cara acak berlapis (proportional cluster random sampling), prosedur pengambilan sampel yang dilakukan pertama-tama membagi populasi berdasarkan kelas yang ada, kemudian dari setiap populasi (kelas) diambil dipilih secara acak masing-masing 20 persen, sehingga jumlah sampel yang ada berjumlah 56 siswa.

Variabel bebas dalam penelitian ini yaitu peran guru IPS sebagai pendidik dan pengajar (X). Sedangkan variabel terikatnya yaitu sikap sosial siswa (Y1), dan tanggung jawab sosial siswa (Y2). Data dikumpulkan dengan menggunakan kuesioner dan dokumentasi.

Analisis data dalam penelitian kuantitatif merupakan kegiatan setelah data dari seluruh responden terkumpul. Kegiatan dalam analisis data adalah: mengelompokkan data berdasarkan variable dan jenis responden, mentabulasi data berdasarkan variabel dari seluruh responden, menyajikan data tiap variabel yang diteliti, melakukan perhitungan untuk menjawab rumusan masalah, dan melakukan perhitungan untuk menguji pertanyaan penelitian yang telah diajukan (Sugiyono, 2008, p.147).

Analisis data dalam penelitian deskriptif langkah-langkahnya yaitu: menghitung persentase, membuat tabel distribusi frekuensi, menentukan kategori, menyajikan data, interpretasi dan analisis data, serta membuat kesimpulan.

Dalam penelitian ini terdapat dua hipotesis, yaitu:

Terdapat pengaruh peran guru IPS sebagai pendidik dan pengajar dalam meningkatkan sikap sosial siswa SMP Negeri 1 Pangkajene Sidrap.

Terdapat pengaruh peran guru IPS sebagai pendidik dan pengajar dalam meningkatkan tanggung jawab sosial siswa SMP Negeri 1 Pangkajene Sidrap.

\section{Hasil Penelitian dan Pembahasan}

Hasil Penelitian

Penelitian dilakukan di SMP Negeri 1 Pangkajene Sidrap, dengan responden siswa kelas VII. Hasil penelitian diuraikan sebagai berikut.

Deskripsi Karakteristik Responden

Tabel 3. Distribusi Frekuensi Jenis Kelamin Responden

\begin{tabular}{cccc}
\hline No & $\begin{array}{c}\text { Jenis } \\
\text { Kelamin }\end{array}$ & Frekuensi & Persentase \\
\hline 1 & Laki-laki & 26 & $46,4 \%$ \\
2 & Perempuan & 30 & $53,6 \%$ \\
& Jumlah & 56 & $100 \%$ \\
\hline
\end{tabular}

Berdasarkan jenis kelamin, responden dengan jenis kelamin laki-laki berjumlah 26 siswa $(46,4 \%)$, sedangkan responden berjenis kelamin perempuan berjumlah 30 siswa $(53,6 \%)$. Proporsi siswa laki-laki dan siswa perempuan dalam penelitian ini mempunyai kecenderungan jumlah yang hampir sama, sehingga tidak ada dominasi berdasarkan jenis kelamin.

Tabel 4. Distribusi Frekuensi Usia Responden

\begin{tabular}{cccc}
\hline No & Usia & Frekuensi & Persentase \\
\hline 1 & 12 tahun & 19 & $33,9 \%$ \\
2 & 13 tahun & 35 & $62,5 \%$ \\
3 & 14 tahun & 2 & $3,6 \%$ \\
& Jumlah & 56 & $100 \%$ \\
\hline
\end{tabular}

Berdasarkan kelompok usia, diketahui bahwa usia responden rata-rata 13 tahun dengan jumlah 35 orang $(62,5 \%)$, siswa yang berusia 12 tahun berjumlah 19 orang $(33,9 \%)$, dan siswa yang berusia 14 tahun berjumlah 2 orang $(3,6 \%)$. Hal tersebut mengindikasikan bahwa siswa masuk sekolah rata-rata sesuai dengan standar usia yang ditetapkan sekolah, dimana siswa kelas VII rata-rata berusia 13 tahun.

\section{Deskripsi Variabel Peran Guru}

Berdasarkan hasil perhitungan nilai masing-masing butir pada variabel peran guru, diketahui bahwa indikasi peran guru yang 
paling tinggi adalah butir pernyataan "guru terlebih dahulu menanyai pendapat siswa sebelum mengambil sebuah keputusan terkait kepentingan kelas" dengan nilai 0,829 atau $82,9 \%$. Indikasi peran guru yang paling rendah adalah butir pernyataan "guru dalam mengajar sering mengaitkan masalah dalam kehidupan sehari-hari sehingga mudah dipahami" dengan nilai 0,456 atau $45,6 \%$. Secara keseluruhan peran guru IPS sebagai pendidik dan pengajar di SMP Negeri 1 Pangkajene Sidrap adalah sebesar 0,627 atau $62,7 \%$.

Rentang skor variabel peran guru dari 35 sampai 140. Deskripsi variabel peran guru dapat dilihat pada Tabel 5.

Tabel 5. Distribusi Frekuensi Data Peran Guru

\begin{tabular}{ccccc}
\hline No & \multicolumn{1}{c}{ Kategori } & Interval & Jumlah & $(\%)$ \\
\hline 1 & Sangat Tinggi & $120-140$ & 38 & 67,86 \\
2 & Tinggi & $99-119$ & 18 & 32,14 \\
3 & Sedang & $78-98$ & 0 & 0 \\
4 & Rendah & $57-77$ & 0 & 0 \\
5 & Sangat Rendah & $35-56$ & 0 & 0 \\
Total & & 56 & 100 \\
\hline
\end{tabular}

Berdasarkan Tabel 5 diketahui bahwa sebagian besar responden cenderung mengatakan bahwa peran guru termasuk dalam kategori sangat tinggi. Sebanyak 38 responden $(67,86 \%)$ mengatakan peran guru sangat tinggi, dan sebanyak 18 responden $(32,14 \%)$ menyatakan peran guru termasuk dalam kategori tinggi.

\section{Deskripsi Variabel Sikap Sosial}

Berdasarkan hasil analisis data diketahui bahwa indikasi sikap sosial siswa yang paling tinggi adalah butir pernyataan "saat siswa ingin meminjam sesuatu milik teman namun orangnya sedang tidak berada di tempat maka sebaiknya menunggu terlebih dahulu untuk meminta ijin walaupun sedang tergesagesa untuk menggunakannya" dengan nilai 0,967 atau $96,7 \%$. Indikasi sikap sosial siswa yang paling rendah adalah butir pernyataan "siswa mau berkejasama kelompok di kelas dengan siapapun walaupun berbeda agama" dengan nilai 0,486 atau $48,6 \%$. Secara keseluruhan sikap sosial siswa SMP Negeri 1 Pangkajene Sidrap adalah sebesar 0,671 atau $67,1 \%$.
Rentang skor variabel sikap sosial siswa dari 42 sampai 168. Deskripsi variabel sikap sosial dapat dilihat pada Tabel 6.

Tabel 6. Distribusi Frekuensi Data Sikap Sosial

\begin{tabular}{ccccc}
\hline No & \multicolumn{1}{c}{ Kategori } & Interval & Jumlah & $(\%)$ \\
\hline 1 & Sangat Tinggi & $144-168$ & 0 & 0 \\
2 & Tinggi & $119-143$ & 54 & 96,4 \\
3 & Sedang & $94-118$ & 2 & 3,6 \\
4 & Rendah & $69-93$ & 0 & 0 \\
5 & Sangat Rendah & $42-68$ & 0 & 0 \\
Total & & 56 & 100 \\
\hline
\end{tabular}

Dilihat dari Tabel 6, diketahui bahwa sebagian besar responden memiliki persepsi terhadap variabel sikap sosial yang termasuk dalam kategori tinggi sebanyak 54 orang (96,4\%). Hal tersebut berarti bahwa sikap sosial yang dimiliki oleh siswa SMP Negeri 1 Pangkajene Sidrap dirasa cukup baik. Hanya terdapat 2 orang $(3,6 \%)$ yang memiliki sikap sosial dalam kategori sedang.

\section{Deskripsi Variabel Tanggung Jawab Sosial}

Berdasarkan penghitungan nilai masing-masing butir pernyataan, dapat diketahui bahwa indikasi tanggung jawab sosial siswa yang paling tinggi adalah butir pernyataan "saat siswa tidak melemparkan kesalahan kepada orang lain atas kesalahan yang dia perbuat sendiri" dengan nilai 0,862 atau $86,2 \%$. Indikasi tanggung jawab sosial siswa yang paling rendah adalah butir pernyataan "PR yang menjadi kewajiban pribadi siswa maka harus dikerjakan sendiri" dengan nilai 0,371 atau $37,1 \%$. Secara keseluruhan tanggung jawab sosial siswa SMP Negeri 1 Pangkajene Sidrap adalah sebesar 0,627 atau $62,7 \%$.

Rentang skor variabel tanggung jawab sosial dari 18 sampai 72. Deskripsi variabel tanggung jawab sosial dapat dilihat pada Tabel 7.

Berdasarkan Tabel 7 diketahui bahwa sebagian besar responden memiliki tanggung jawab sosial yang sangat tinggi, yaitu sebanyak 43 orang $(76,8 \%)$. Sedangkan 11 orang responden $(19,6 \%)$ memiliki memiliki tanggung jawab sosial tinggi dan sebanyak 2 orang $(3,6 \%)$ memiliki tanggung jawab sosial sedang. 
Tabel 7. Distribusi Frekuensi Data Tanggung Jawab Sosial

\begin{tabular}{clccc}
\hline No & Kategori & Interval & Jumlah & $(\%)$ \\
\hline 1 & Sangat Tinggi & $62-72$ & 43 & 76,8 \\
2 & Tinggi & $51-61$ & 11 & 19,6 \\
3 & Sedang & $40-50$ & 2 & 3,6 \\
4 & Rendah & $29-39$ & 0 & 0 \\
& Sangat & $18-28$ & 0 & 0 \\
& Rendah & & 56 & 100 \\
\hline
\end{tabular}

Uji Normalitas

Tabel 8. Hasil Uji Normalitas

\begin{tabular}{lcc}
\hline \multicolumn{1}{c}{ Variabel } & $\begin{array}{c}\text { Kolmogorov- } \\
\text { Smirnov }\end{array}$ & $\begin{array}{c}\text { Asymp. Sig. } \\
\text { (2-tailed) }\end{array}$ \\
\hline Peran Guru & 0.729 & 0.663 \\
Sikap Sosial & 0.674 & 0.754 \\
Tanggung & 1.252 & 0.087 \\
Jawab Sosial & & \\
\hline
\end{tabular}

Berdasarkan Tabel 8 diperoleh hasil untuk variabel peran guru nilai signifikansinya sebesar 0,663 , variabel sikap sosial signifikansinya sebesar 0,754 , dan variabel tanggung jawab sosial dengan nilai signifikansi sebesar 0,087. Ketiga variabel tersebut memiliki nilai signifikansi lebih besar dari 0,05 , maka hasil uji normalitas menunjukkan bahwa variabel peran guru, sikap sosial, dan tanggung jawab sosial berdistribusi normal.

Uji Linearitas

Tabel 9. Hasil Uji Linearitas

\begin{tabular}{llccc}
\hline $\begin{array}{c}\text { Variabel } \\
\text { Independen }\end{array}$ & $\begin{array}{c}\text { Variabel } \\
\text { Dependen }\end{array}$ & $\begin{array}{c}\text { Sig. } \\
\text { Linearity }\end{array}$ & $\begin{array}{c}\text { Sig. Deviation } \\
\text { from Linearity }\end{array}$ & Ket. \\
\hline Peran Guru & Sikap Sosial & 0.000 & 0.256 & Linear \\
Peran Guru & $\begin{array}{l}\text { Tanggung } \\
\text { Jawab Sosial }\end{array}$ & 0.000 & 0.688 & Linear \\
\hline
\end{tabular}

Tabel 9 menunjukkan bahwa semua bentuk hubungan antar variabel dinyatakan linear. Hubungan variabel peran guru terhadap sikap sosial terbukti linear dengan nilai probabilitas linearity $0,000<0,05$ dan nilai probabilitas deviation from linearity 0,256> 0,05 . Hubungan variabel peran guru terhadap tanggung jawab sosial juga terbukti linear dengan nilai probabilitas linearity $0,000<$ 0,05 dan nilai probabilitas deviation from linearity $0,688>0,05$.
Pengujian Hipotesis

Tabel 10. Hasil Pengujian Hipotesis 1

\begin{tabular}{lcccc}
\hline Hipotesis & $\mathrm{T}$ & $\mathrm{R}^{2}$ & $\mathrm{~F}$ & $\begin{array}{c}p- \\
\text { value }\end{array}$ \\
\hline $\begin{array}{l}\text { Peran Guru } \rightarrow \\
\text { Sikap Sosial }\end{array}$ & 9.715 & 0.636 & $\begin{array}{c}94.37 \\
0.000\end{array}$ \\
\hline
\end{tabular}

Berdasarkan hasil analisis regresi untuk hipotesis 1 pada Tabel 10 diperoleh nilai $\mathrm{F}$ hitung sebesar 94,373 dengan $p$-value 0,000 . Karena $p$-value kurang dari 0,05 maka Ha diterima. Artinya terdapat pengaruh yang signifikan peran guru mata pelajaran IPS sebagai pendidik dan pengajar terhadap sikap sosial siswa. Hasil analisis diperoleh nilai $\mathrm{t}$ hitung sebesar 9,715 yang menunjukkan angka positif, berarti ada hubungan positif antara peran guru dengan sikap sosial siswa.

Nilai koefisien determinasi sebesar 0,636 atau $63,6 \%$ menunjukkan bahwa sikap sosial siswa dipengaruhi oleh peran guru mata pelajaran IPS sebagai pendidik dan pengajar sebesar $63,6 \%$, sedangkan $36,4 \%$ dipengaruhi oleh faktor lain yang tidak dijelaskan dalam penelitian ini.

Tabel 11. Hasil Pengujian Hipotesis 2

\begin{tabular}{ccccc}
\hline Hipotesis & $\mathrm{T}$ & $\mathrm{R}^{2}$ & $\mathrm{~F}$ & $\begin{array}{c}p- \\
\text { value }\end{array}$ \\
\hline $\begin{array}{l}\text { Peran Guru } \\
\rightarrow \text { Tanggung } \\
\text { Jawab Sosial }\end{array}$ & 4.146 & 0.241 & 17.187 & 0.000 \\
\hline
\end{tabular}

Hasil analisis regresi untuk hipotesis 2 pada Tabel 11 menunjukkan bahwa nilai $\mathrm{F}$ hitung untuk hipotesis 2 sebesar $17,187 \mathrm{de}$ ngan $p$-value 0,000 . Nilai $p$-value $0,000<$ 0,05 maka Ha diterima dan Ho ditolak. Hal tersebut berarti hubungan peran guru IPS sebagai pendidik dan pengajar dalam meningkatkan tanggung jawab sosial siswa terbukti berpengaruh secara signifikan.

Nilai t hitung diperoleh sebesar 4,146 yang menunjukkan angka posistif, yang menunjukkan hubungan positif antara peran guru dengan tanggung jawab sosial siswa. Nilai koefisien determinasi $\left(\mathrm{R}^{2}\right)$ hipotesis 2 diperoleh sebesar 0,241 atau $24,1 \%$, yang artinya tanggung jawab sosial siswa dipengaruhi oleh peran guru IPS sebagai pendidik dan pengajar sebesar $24,1 \%$, dan $76,9 \%$ dipenga- 
ruhi oleh faktor lain yang tidak disebutkan dalam penelitian ini.

Pembahasan

Peran Guru IPS sebagai Pendidik dan Pengajar di SMP Negeri 1 Pangkajene Sidrap

Berdasarkan analisis data dari hasil pembahasan diketahui bahwa peran guru IPS sebagai pendidik dan pengajar sebesar $62,7 \%$. Hal tersebut berarti bahwa siswa merasakan peranan guru cukup penting dalam proses pembelajaran di sekolah.

Contoh peran guru sebagai pendidik yang ada di SMP Negeri 1 Pangkajene Sidrap yaitu memberikan penjelasan mengenai kerugian dari melakukan kecurangan dalam mengerjakan tugas, guru mengajak murid untuk peduli terhadap lingkungan, guru sering memberikan nasehat pada siswa, serta guru menghargai pendapat dari siswa. Sedangkan peran guru sebagai pengajar juga direspon positif oleh siswa, dimana siswa merasakan bahwa guru menyampaikan materi pelajaran dengan baik dan mudah dipahami oleh siswa. Beberapa contohnya yaitu guru memberikan ilustrasi mengenai suatu permasalahan, guru menggunakan media yang beragam dalam menyampaikan materi, serta melibatkan siswa dalam penggunakan media pembelajaran guna melatih keterampilan siswa.

\section{Sikap Sosial Siswa SMP Negeri 1 Pangkajene Sidrap}

Berdasarkan data yang telah dianalisis, sikap sosial siswa SMP Negeri 1 Pangkajene Sidrap sebesar $67,1 \%$. Hal tersebut berarti siswa SMP Negeri 1 Pangkajene Sidrap telah memiliki sikap sosial yang baik, baik yang bersifat bawaan maupun yang sudah dikembangkan oleh guru atau orang tua.

Siswa yang telah memiliki bawaan sikap sosial yang baik tentu akan lebih mudah untuk dikembangkan, berbeda dengan siswa yang sikap sosialnya masih kurang baik, guru harus lebih sering memberikan contoh kebiasaan sikap sosial pada siswa tersebut untuk dapat meningkatkan sikap sosialnya.

Tanggung Jawab Sosial Siswa SMP Negeri 1 Pangkajene Sidrap

Tanggung jawab sosial siswa SMP Negeri 1 Pangkajene Sidrap sebesar 62,7\%.
Hal tersebut membuktikan bahwa tanggung jawab sosial siswa SMP Negeri 1 Pangkajene Sidrap sebagian besar sudah cukup baik. Siswa yang memiliki tanggung jawab sosial yang baik dapat dilihat dari sikap siswa yang berani mengakui kesalahannya, tidak menyontek pekerjaan teman, tidak menuduh teman tanpa bukti, tidak menunda-nunda pekerjaan yang diberikan guru, serta mengerjakan tugas yang diberikan guru dengan tepat waktu.

\section{Peran Guru IPS sebagai Pendidik dan Pengajar dalam Meningkatkan Sikap Sosial Siswa}

Berdasarkan hasil analisis data di atas, dapat disimpulkan bahwa peran guru IPS sebagai pendidik dan pengajar berpengaruh signifikan terhadap sikap sosial siswa dengan kontribusi sebesar $63,6 \%$. Peran guru IPS sebagai pendidik dan pengajar berpengaruh dalam meningkatkan sikap sosial siswa karena ketika pembelajaran di kelas, guru IPS tidak hanya memberikan materi pada siswa saja, tetapi juga memberikan teladan pada siswanya dengan bersikap disiplin, mandiri serta berkepribadian baik.

Peran guru mata pelajaran IPS sebagai pendidik dan pengajar berpengaruh terhadap sikap sosial siswa karena ketika pembelajaran di kelas, guru mata pelajaran IPS tidak hanya memberikan materi pada siswa saja, tetapi juga memberikan teladan pada siswanya dengan bersikap disiplin, mandiri serta berkepribadian baik. Sebagaimana dijelaskan oleh Mulyasa (2011, p. 37) bahwa guru sebagai pendidik harus menjadi tokoh panutan bagi siswa dan lingkungannya, sedangkan guru sebagai pengajar harus membantu siswa yang sedang berkembang untuk mempelajari sesuatu yang belum diketahuinya. Guru yang sering membiasakan hal-hal baik pada siswanya akan lebih cepat dalam membentuk sikap sosial siswa.

Guru mengajarkan sikap sosial siswa tidak hanya sebatas untuk mencapai kompetensi dasar siswa saja, melainkan juga untuk menanamkan dalam diri siswa agar nantinya siswa dapat menerapkannya di lingkungan masyarakat, rumah dan sekolah. Siswa yang dalam dirinya sudah tertanam sikap sosial cenderung memiliki sifat jujur, pemaaf, suka menolong teman, sopan terhadap orang yang lebih tua, menghormati pendapat orang lain, 
dan juga menghargai guru. Maka dari itu, untuk menghindari melemahnya sikap sosial siswa karena arus perkembangan zaman, guru di sekolah harus terus mendidik dan menjadi contoh bagi siswa dalam mengembangkan sikap sosial siswa.

\section{Peran Guru IPS sebagai Pendidik dan Pengajar dalam Meningkatkan Tanggung Jawab Sosial Siswa}

Peran guru IPS sebagai pendidik dan pengajar memiliki kontribusi sebesar $24,1 \%$ terhadap tanggung jawab sosial siswa SMP Negeri 1 Pangkajene Sidrap. Tanggung jawab sosial menurut Simorangkir (1987, p.155) merupakan kemampuan manusia dalam kehidupan bermasyarakat dalam menjaga keseimbangan antara perilaku yang ditampilkan dengan harapan sesuai dengan status sosialnya.

Peran guru IPS sebagai pendidik dan pengajar berpengaruh dalam meningkatkan tanggung jawab sosial siswa karena guru mengajarkan pada siswa untuk mengakui kesalahan yang diperbuat, memberikan kepercayaan pada siswa untuk menjadi pemimpin ketika diskusi kelompok, segera melaksanakan tugas yang diberikan guru, serta membiasakan untuk segera mengembalikan barang yang dipinjamnya. Melalui cara-cara tersebut, guru akan lebih mudah dalam mengajarkan tanggung jawab sosial siswa daripada hanya dengan memberikan teori semata.

Hasil penelitian ini sejalan dengan hasil penelitian Suparman (2015) yang bertujuan untuk mengetahui hubungan peranan guru terhadap sikap dan tanggung jawab sosial siswa di sekolah dasar. Dalam penelitiannya menyebutkan bahwa terdapat hubungan peranan guru sekolah dasar terhadap sikap tanggung jawab sosial siswa sekolah dasar se-Kecataman Labuhan Ratu. Ia juga menyimpulkan apabila peranan guru di sekolah dasar baik maka sikap tanggung jawab sosial siswa juga akan baik, sedangkan apabila peranan guru di sekolah masih kurang baik maka sikap tanggung jawab sosial siswa di sekolah akan kurang baik pula.

Upaya yang dilakukan oleh guru SMP

Negeri 1 Pangkajene Sidrap dalam membina tanggung jawab sosial siswa yaitu dengan mengajarkan pada siswa untuk tidak meyalahkan orang lain atas kesalahannya, tidak mencontek pekerjaan teman ketika ulangan, mengembalikan barang yang bukan menjadi miliknya, membiasakan siswa untuk bersamasama mengerjakan tugas kelompok, serta membiasakan siswa untuk melaksanakan piket kelas. Upaya-upaya tersebut secara perlahan dapat menumbuhkan tanggung jawab sosial dalam diri siswa.

\section{Simpulan}

Berdasarkan hasil penelitian dan pembahasan dalam penelitian ini, maka dapat disimpulkan sebagai berikut:

Sumbangan peran guru IPS sebagai pendidik dan pengajar di SMP Negeri 1 Pangkajene Sidrap menurut pendapat siswa kelas VII yaitu sebesar $62,7 \%$. Sumbangan sikap sosial siswa SMP Negeri 1 Pangkajene Sidrap adalah sebesar $67,1 \%$. Sumbangan tanggung jawab sosial siswa SMP Negeri 1 Pangkajene Sidrap yaitu sebesar $62,7 \%$.

Peran guru IPS sebagai pendidik dan pengajar terbukti berpengaruh signifikan positif dalam meningkatkan sikap sosial siswa SMP Negeri 1 Pangkajene Sidrap. Peran guru IPS sebagai pendidik dan pengajar terbukti berpengaruh signifikan positif dalam meningkatkan tanggung jawab sosial siswa SMP Negeri 1 Pangkajene Sidrap.

Berdasarkan kesimpulan hasil penelitian tersebut, implikasi dari hasil penelitian ini yaitu peran guru IPS dapat meningkatkan sikap sosial dan tanggung jawab sosial siswa SMP Negeri 1 Pangkajene Sidrap dengan memberikan contoh-contoh sikap sosial dan tanggung jawab sosial dan keteladanan secara spontan ketika di sekolah, sehingga siswa lebih mudah mengaplikasikan dan mengembangkan sikap tersebut dalam dirinya.

Berdasarkan kesimpulan penelitian, saran yang dapat diberikan yaitu sebagai berikut. Guru dapat mengembangkan sikap sosial dan tanggung jawab sosial siswa dengan memberikan contoh kebiasaan baik pada siswa. Selain itu guru juga harus lebih memperhatikan sikap sosial siswa ketika di sekolah, agar guru dapat langsung menegur siswa yang melakukan kesalahan. Siswa harus lebih menghargai guru yang sedang mengajar di kelas. Serta siswa perlu untuk lebih memahami pentingnya sikap sosial dan tanggung jawab sosial dalam kehidupan bermasyarakat.

\section{Daftar Pustaka}

Ahmadi, A. (2009). Psikologi sosial. Jakarta: Rineka Cipta. 
Darmadi, H. (2010). Kemampuan dasar mengajar. Bandung: Alfabeta.

Gunawan, R. (2011). Pendidikan IPS filosofi, konsep dan aplikasi. Bandung: Alfabeta.

Hamalik, O. (2009). Proses belajar mengajar. Jakarta: Bumi Aksara.

Hamond, L. D. (2006). Powerful teacher education: lessons from exemplary programs. San Francisco: Jossey-Bass.

Hellison, D. R. (2003). Teaching personal and social responsibility through physical activity. Third Edition. USA: Human Kinetics, Inc.

Inglis, F., \& Aers, L. (2008). Key concepts in education. Los Angeles: SAGE Publication.

Juniar, D. P. (2010). Upaya guru dalam membina tanggung jawab sosial siswa di lingkungan sekolah menengah atas: studi deskriptif tentang pembinaan tanggung jawab sosial siswa sebagai upaya mengembangkan anak didik berakhlak mulia di Baleendah-Bandung. Thesis, Univeristas Pendidikan Indonesia.

Kementerian Pendidikan dan kebudayaan. (2014). Model penilaian pencapaian kompetensi peserta didik sekolah menengah pertama. Direktorat Pembinaan Sekolah Menengah Pertama.

Kementerian Pendidikan dan kebudayaan. (2015). Panduan penilaian untuk Sekolah Menengah Pertama (SMP). Direktorat Pembinaan Sekolah Menengah Pertama.

Koesoema, D. (2009). Pendidikan karakter di zaman keblinger. Jakarta: Grasindo.

Lickona, T. (2013). Mendidik untuk membentuk karakter: bagaimana sekolah dapat memberikan pendidikan tentang sikap hormat dan tanggung jawab. (Terjemahan Juma Abdu Wamaungo). Jakarta: Bumi Aksara.

Massialas, B. G., \& Allen, R. F. (1996). Critical issues in teaching social studies $K$-12. USA: Wadsworth Publishing Company.

Mulyasa, E. (2011). Menjadi guru profesional: menciptakan pembelajaran kreatif dan menyenangkan. Bandung: PT Remaja Rosdakarya.

Nursid, N. (2008). Konsep dasar IPS. Jakarta: Universitas Terbuka.

Risthantri, P., \& Sudrajat, Ajat. (2015). Hubungan antara pola asuh orang tua dan ketaatan beribadah dengan perilaku sopan santun peserta didik. Harmoni Sosial: Jurnal Pendidikan IPS, (2), . 2, pp. 191-202, Retrieved from: http://journal.uny.ac.id/index.php/hsjpi/a $\underline{\text { rticle/view/7670 }}$

Rusyan, T. (1990). Kemampuan dasar guru dalam proses belajar mengajar. Bandung: PT. Remaja Rosdakarya.

Sapriya. (2009). Pendidikan IPS konsep dan pembelajaran. Bandung: PT. Remaja Rosdakarya.

Sardjiyo. (2007). Pendidikan IPS di SD. Jakarta: Universitas Terbuka.

Simorangkir. (1987). Tanggung jawab manusia. Jakarta: Rineka Cipta.

Sudarsono. (1997). Kamus konseling. Jakarta: Rineka Cipta.

Sugiyono. (2008). Metode penelitian pendidikan. Bandung: Alfabeta.

Suparman, D. (2015). Hubungan peranan guru sekolah dasar dengan sikap tanggung jawab siswa. Jurnal pedagogi, 2(7)

Depdiknas. (2003). Undang-Undang Nomor 20 Tahun 2003 tentang Sistem Pendidikan Nasional

UNICEF. (2014). Laporan tahunan indonesia 2014. Genewa: PBB.

Usman, H. (2006). Manajemen teori-praktik dan riset pendidikan. Jakarta: Bumi Aksara.

Wijaya, E. P. (2015). Peran guru dalam pembentukan perilaku bertanggung jawab peserta didik. Jurnal kultur demokrasi, 3(8).

Zuriah, N. (2007). Pendidikan moral \& budi pekerti dalam perspektif perubahan. Jakarta: Bumi Aksara. 